\title{
RELATIONSHIP BETWEEN MARKET ORIENTATION AND INNOVATIVENESS IN COMPANIES
}

\author{
$\check{S ̆ L O G A R ~ H e l e n a ~}^{1}$ \\ ${ }^{1}$ Libertas International University, Zagreb (CROATIA) \\ E-mail: hslogar@libertas.hr
}

\begin{abstract}
Market orientation as a marketing concept has an impact on innovative processes in companies. The aim of this research is to examine whether there is a positive relation between market orientation and innovativeness in Croatian companies. The research was conducted on a sample of 303 Croatian companies using a survey questionnaire. Data were analyzed using the Spearman rank correlation, canonical analysis and cluster analysis. The results show that there is a statistically significant positive correlation between market orientation and innovativeness in companies. This research contributes to the consideration of the interconnectedness of constructs that can provide useful insights into their content and joint influences on the positioning of innovative enterprises in the international market.
\end{abstract}

Keywords: innovativeness, market orientation, customer orientation, competitor orientation, interfunctional coordination

JEL: O31, M31

DOI: 10.5937/intrev2103021S

UDC: $005.342 / .346$

COBISS.SR-ID 55044617 


\section{INTRODUCTION}

In order to achieve competitive advantage, companies must be able to provide their customers with superior products and services. This requires a special understanding of the industry in which the company operates and its macro-environment. ,Market orientation is the organization-wide generation of market intelligence pertaining to present and future customer needs, the spreading of the intelligence across departments, and organization-wide response to it”. Kohli,. Jaworski [1:6]. Most of the market orientation studies explore three components first defined by Kohli and Jaworski [1] and later by Narver and Slater [2] thus forming a common basis for reflecting market orientation. These studies were conducted with the aim of developing the theory of market orientation and operationalization of the concept with emphasis on the future implications of market orientation. The aim of the research is to determine whether there is a positive relationship between market orientation and innovativeness in companies. Theoretical and empirical research on foreign markets, conducted by numerous authors, has confirmed a positive correlation between market orientation and innovativeness in companies. The basis of market orientation is monitoring the business environment through the constant collection of information about customers, competitors and other stakeholders that affect the business of the company. Companies are researching the initial level of customer satisfaction so that they can improve further communication. This emphasizes the importance of information dissemination, coordination and commitment in the implementation of information in making marketoriented decisions. Market orientation does not work equally in all branches of activity. The above depends on different moderators, for example, customer strength, market turbulence, technological change, intensity of competition, demand-side factors and others. In this study, the research question is: Is market orientation positively related to innovativeness in Croatian companies? The findings of scientific research confirm that these are significant factors in business success. The results of recent research confirm the existence of the observed relationship, but also emphasize that the relationship has not been sufficiently researched [4][5][6][7][8]. Through the successful implementation of market orientation, competitive advantages are created that become a fundamental part of the organizational culture of the company. This study organized in the following way: first, the literature on market orientation is defined as cultural constructs, including values and indicators of behaviour and innovativeness. After defining the hypothesis, the research methodology is stated and research results obtained. The conclusion is drawn on the basis of theoretical and practical implications. The following research hypothesis was developed and tested: There is a positive relationship between the market orientation and innovativeness in Croatian companies.

\section{THE CONCEPT OF MARKET ORIENTATION}

Numerous studies confirm that market orientation (MO) is based on a marketing concept [9][10]. Narver and Slater [11] define market orientation as "the organizational culture that most effectively and efficiently creates the necessary behaviours for the creation of superior value for buyers and, thus, continuous superior performance for the business." Narver and Slater [12] differentiate three dimensions of market orientation: customer orientation, competitor orientation, and interfunctional coordination. These scholars also show different directions from the decision-making approach Benson P. Shapiro [13] access to market information Bernard, J. Jaworski and Ajay, K. Kohli (1993), [14]; Judy A. Siguaw, Penny M. Simpson and Thomas L. Baker[15]; access to consumers Rohit Deshpandé, John U. Farley and Frederick, E. Webster [16]. Several studies criticized the concept of market orientation (e.g. Claire Gauzente [17]; Christian Homburg and Christian [18] with regards to the definition and its measurement . They noted that Narver and Slater [19] defined market orientation from a cultural perspective, their measures do not reflect the cultural part of market orientation, but rather measure three behavioural components. On the other hand, Hult, Hurley and Knight [20] confirm a market orientation has a significant positive effect on innovativeness in companies. It has also been found that the market orientation has a direct positive impact on organizational innovativeness [21]. Market orientation has been identified as a prominent variable in the relationship between innovation and performance in small and large firms [22][23][24].

In the study, Sylvie Laforet (2008) [25] links innovation to the company's strategic orientations on a sample of 500 SMEs. The findings show that size, strategic and market orientation are related to a company's innovation. According to Clay Dibrell, Justin B. Craig, Eric N. Hansen [26] firms will be more inclined to modify products if the intensity of market orientation is higher. In the study Hasni N. Juhdi, Tih Sio Hong 
and Nurita [27] show that entrepreneurial learning intensity, market orientation and entrepreneurial success are significantly related. Nathaniel Boso, Vicky M. Story, John W. Cadogan and Ebenezer Ashie [28] state that levels of market orientation and networks of business and social ties are aligned in entrepreneurial firms operating in developing economies. Likewise, Cai, Liu, Zhu and Deng Li Cai, Qing Liu, Xiumei Zhu, Shengliang Deng [29] emphasized that entrepreneurial support policies will strengthen the relationship between market orientation and radical innovation in China companies. Moreover, Mohd Noor Mohd Shariff, Nifaosan Raden Ahmad and Muhammad Haroon Hafeez00 [30] indicated a positive relationship between market orientation, learning orientation, entrepreneurial orientation and SME performance. It can be established that all the above research was conducted with the aim of developing the theory of market orientation and operationalization of the concept with an emphasis on the future implication s of market orientation [31].

\section{INNOVATIVENESS IN COMPANIES}

The notion of innovativeness is discussed in great detail in scientific literature [32][33]. Jaworski and Kohli [34: 56] have argued that "market orientation essentially involves doing something new or different in response to market conditions; it may be viewed as a form of innovative behaviour". Deshpandé et al. [35] speculated that there is a strong link between market orientation and innovativeness that helps achieve top business performance. Similarly, Stanley and Narver [36] consider innovativeness as one of the key abilities to create value that triggers market orientation. Innovativeness is associated with the ability to introduce new ideas, products and processes into the company [37]. In this study, the innovativeness of the firm is defined as the propensity to create new products, manufacturing processes, and business systems [38]. Hult et al. [39] found that there is a positive relationship between innovativeness and market orientation. Market orientation is the most important determinant of business success and has a strong impact on innovativeness under high market turbulence. At that time, customers' preferences and wishes are changing rapidly and businesses are forced to constantly offer new products. Meta-analysis about empirical studies on market orientation conducted by Kirca, Jayachandran and Bearden[40] showed that market orientation exerts an influence on a company by influencing innovativeness, quality and customer loyalty. It can be concluded that innovativeness achieves its goal if product and service users bring added value and therefore a competitive advantage for the company. Kaya and Patton [41] observed an important effect between learning orientation, knowledge-based resources, innovation performance and market orientation in companies.

Ozkaya et al [42] observed that market-based innovation mediates the positive relationships between competitor knowledge competencies and customer and overall firm performance. Similarly, Didonet Díaz and Machado [43] found a positive relationship between the three components of market orientation and different sources of knowledge for innovation in small and medium enterprises. In the study Astrid Puspaningrum [44] argued that innovation has a significant effect on the competitive advantage which is an indicator of technical innovation. Likewise, market orientation affects the competitive advantage which is an indicator of competitor orientation in SMEs companies. Moreover, Thamrin and Firma [45] found that market orientation has a significant effect on innovation in small business enterprise. Sulistiyani Sutarlan [46] proved the positive effect of innovation on market performance and the positive effect of market orientation on market performance. According to Ratih Indriyani, Suprapto and Calista [47] market orientation has a significant and positive impact on the innovation of traditional SMEs in Indonesia. Moreover, Šlogar and Bezić [48] stated that in Croatian companies there is a positive relationship between innovativeness and exports, which has a positive effect on creating their competitiveness in the market.

\section{RESEARCH METHODS}

The paper starts from the assumption that innovative companies are more market-oriented in the international market. Therefore, the hypothesis is set: There is a positive relationship between market orientation and innovativeness in Croatian companies. The analysis was conducted on a sample of 303 Croatian companies using a structured survey questionnaire. The design of the samples included companies from the Register of Business Entities of the Croatian Chamber of Commerce. The survey was conducted in the period from October to December 2016 using an online questionnaire and the respondents were 
company directors, department heads in the company. The pilot test was used to check the subject of the questionnaire and was adapted to Croatian companies. The market orientation measurement scale MKTOR Narver and Slater [49] consists of three components: consumer orientation, competition orientation and interfunctional coordination, and a total of 15 statements, and is measured by the Likert scale (1-5). The scale, which measures enterprise innovativeness, consists of three components of product innovation, process innovativeness and business system innovativeness a total of 15 statements, and is measured by the Likert scale (1-5) Nybbak, [50]. To prove the hypothesis, a Spearman Rank Order Correlations was used to structure the correlation of individual responses. Canonical analysis tests the relationship between the two data sets, market orientation and innovation. Cluster analysis graphically shows the structure of the connection between market orientation and innovativenss. Statistical analysis of data was performed by the program STATISTICA 6.1 StatSoft inc. 1983-2003.

\section{RESEARCH RESULTS}

Table 1. Distribution of respondents by gender and function in the company $(N=303)$

\begin{tabular}{|c|c|c|c|}
\hline Function in the company & \begin{tabular}{|l} 
Gender \\
Male \\
\end{tabular} & \begin{tabular}{|l} 
Gender \\
Femail
\end{tabular} & Total \\
\hline 1 - President of the board / director of the company & 48 & 5 & 53 \\
\hline$\%$ & $15.84 \%$ & $1.65 \%$ & $17.49 \%$ \\
\hline 2 - Director of research and development/marketing & 36 & 24 & 60 \\
\hline$\%$ & $11.88 \%$ & $7.92 \%$ & $19.80 \%$ \\
\hline 3 - Director of production / logistics & 45 & 12 & 57 \\
\hline$\%$ & $14.85 \%$ & $3.96 \%$ & $18.81 \%$ \\
\hline 4 - Director of finance / accounting & 30 & 13 & 43 \\
\hline$\%$ & $9.90 \%$ & $4.29 \%$ & $14.19 \%$ \\
\hline 5 - Director of other organizational sectors & 65 & 25 & 90 \\
\hline$\%$ & $21.45 \%$ & $8.25 \%$ & $29.70 \%$ \\
\hline Total & 224 & 79 & 303 \\
\hline$\%$ & $73.93 \%$ & $26.07 \%$ & \\
\hline
\end{tabular}

Source: Research author

The results in Table 1. show that 224 men and 79 women participated in the study. Most respondents hold the position of director of other organizational sectors $29.70 \%$, followed by director of research and development / marketing 19.80\%, director of production / logistics 18.81\%, CEO / director of the company $17.49 \%$ and director of finance / accounting $14.19 \%$. The largest difference between the number of men and the number of women by function was recorded in the position of President of the Management Board / Director of the company, where 48 men and only 5 women were classified.

Table 2. Distribution of companies according to-NKPJS-HR $(N=303)$

\begin{tabular}{|l||l|l|l|l||}
\hline NKPJS - HR & Small companies & Middle companies & Large companies & Total \\
\hline \hline HR 01 & 64 & 50 & 44 & 158 \\
\hline \hline HR 02 & 40 & 23 & 37 & 100 \\
\hline \hline HR 03 & 31 & 11 & 3 & 45 \\
\hline Total & 135 & 84 & 84 & 303 \\
\hline
\end{tabular}

HR 01-North-western Croatia; HRO2 - Central and Eastern Croatia ; HRO3 - Adriatic Croatia Source: Research author 
Table 2. shows the distribution of companies according to The National Classification of Territorial Units for Statistics (NKPJS) from 2007 (Official Gazette No. 35/2007) into three regions. The survey involved 64 small enterprises, 50 medium and 44 large enterprises from HR 01-region, 40 small, 23 medium and 37 large enterprises from HR 02- region and 31 small, 11 medium and only three large enterprises from HR 03-region.

Table 3. Distribution of companies by sales of products on the market $(N=303)$

\begin{tabular}{|l|l||l||}
\hline Frequency table & Number & Percentage (\%) \\
\hline Market & 97 & 32,1 \\
\hline National market / Republic of Croatia & 78 & 25,7 \\
\hline Regional market & 128 & 42,2 \\
\hline International market & 303 & 100,0 \\
\hline Total
\end{tabular}

Source: Research author

In Table 3. the results show that the Companies sold the most products on the international market, $42.2 \%$, followed by $32.1 \%$ on the domestic market and $25.7 \%$ on the regional market.

Table 4. Distribution of companies by profile of exported products/ services $(N=303)$
\begin{tabular}{|l|l|l|}
\hline Frequency table & Pumber & Percentage (\%) \\
\hline Profile of exported products / services & 32 & 10,6 \\
\hline Semi-finished products & 241 & 79,5 \\
\hline Finished products & 30 & 9,9 \\
\hline Services & 303 & 100,0 \\
\hline \hline Total &
\end{tabular}

Source: Research author

In table 4. the results show that among exported products, finished products predominate, $79.5 \%$, semifinished products $10.6 \%$ and services $9.9 \%$.

Table 5. Spearman Rank Order Correlations

\begin{tabular}{|c|c|c|c|c|}
\hline \multicolumn{5}{|c|}{ All correlations are significant at $\mathrm{p}<0.05$} \\
\hline & Innovativeness & $\begin{array}{l}\text { Product } \\
\text { innovation }\end{array}$ & $\begin{array}{l}\text { Process } \\
\text { innovativeness }\end{array}$ & $\begin{array}{l}\text { Business system } \\
\text { innovativeness }\end{array}$ \\
\hline Customer orientation & 0.644 & 0.652 & 0.518 & 0.518 \\
\hline Competitor orientation & 0.676 & 0.658 & 0.508 & 0.619 \\
\hline Interfunctional orientation & 0.590 & 0.609 & 0.503 & 0.457 \\
\hline
\end{tabular}

Source: Research author

In Table 5. by implementing the Spearman rank correlation it has been shown that there is a statistically significant positive relation between customer orientation, competitor orientation, interfunctional coordination and product innovation, process innovativeness and business system innovativeness in companies $(\mathrm{p}<0.05)$.

Table 6. Canonical Analysis

\begin{tabular}{|l|l|l|}
\hline Canonical Analysis Summary Canonical R: ,82165 Chi2(225)=877,87 $\mathrm{p}<0,01$ \\
\hline \hline & Market orientation & Innovativeness \\
\hline \hline No. of variables & 15 & 15 \\
\hline \hline Variance extracted & $100.000 \%$ & $100.000 \%$ \\
\hline Total redundancy & $39.2744 \%$ & $36.1262 \%$ \\
\hline
\end{tabular}

Source: Research author 
In Table 6 canonical analysis show a positive relationship between the two data sets of market orientation and innovativeness and amounts to Canonical R: 0. 82165. Statistical sagnificance was tested by Chi-square test Chi2 $(225)=877.87$. that shows a statistically significant correlation $(\mathrm{p}<0.01)$.

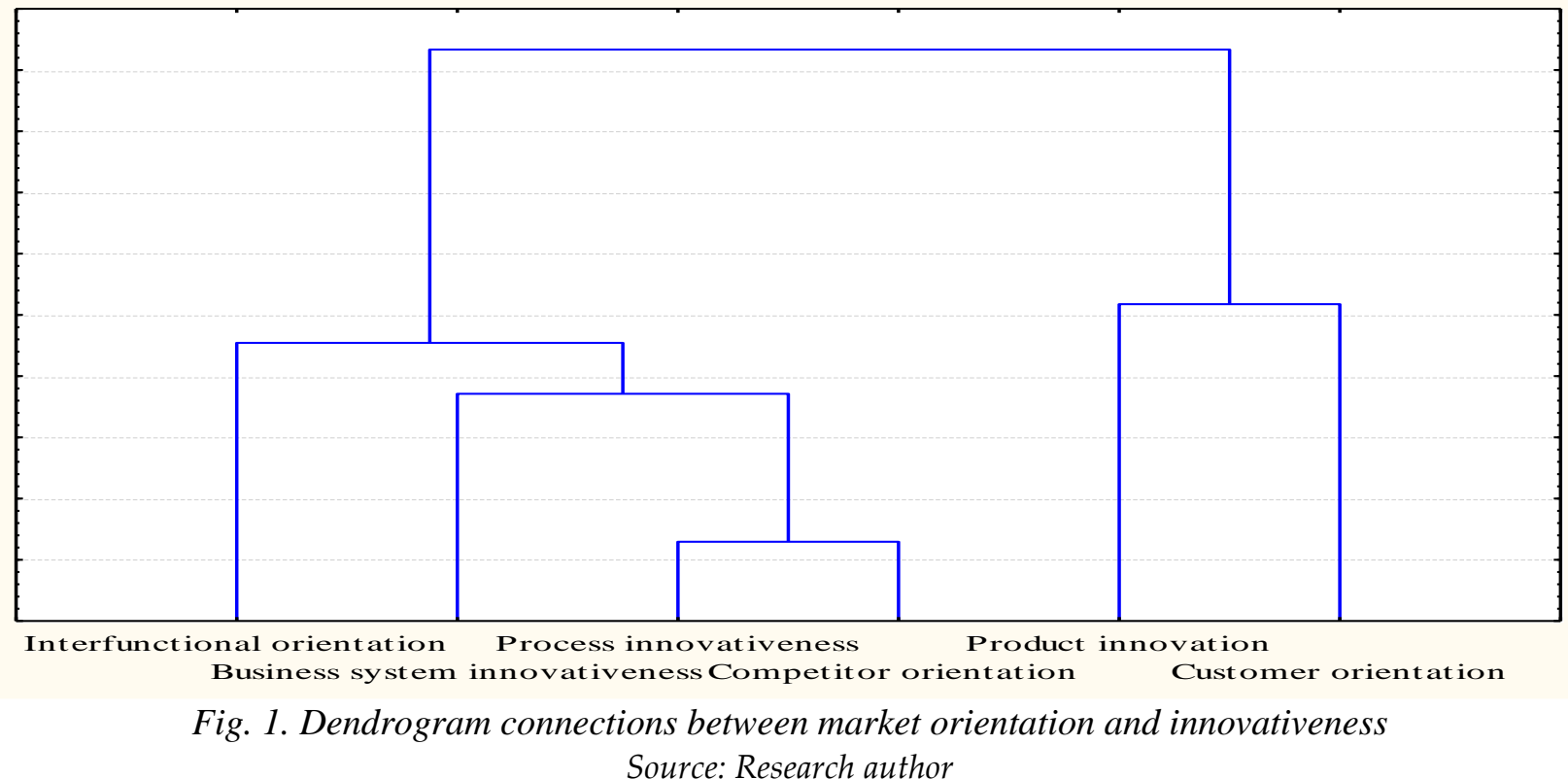

In Figure 1. cluster analysis graphically shows the relationship structure of the three dimensions of market orientation (Customer orientation, Competitor orientation, Interfunctional orientation) and the three dimensions of innovativeness (product innovation, process innovativeness and business system innovativeness). The illustrated empirical results in Figure 1 confirm the positive relationship between market orientation and innovation with the ultimate goal of creating a successful business. Based on the conducted analysis, it can be established that the respondents evaluated the offered sources for creating market orientation and innovation of companies in the market. According to the above findings, the hypothesis was fully confirmed.

\section{DISCUSSION AND CONCLUSION}

The goal of market orientation is to create a constant competitive advantage by providing customers with top-notch products and services when compared to their competitors. The results of this research show a positive relationship between market orientation and innovativeness which is in line with previous research [51]. The results show that there is a statistically significant positive correlation between the correlation of each pair of variables, market orientation and innovativeness, and that there are statistically significant correlation coefficients $(\mathrm{p}<0.05)$. With the growth of activities related to consumer orientation, competition orientation and interfunctional coordination in companies, the growth of product innovation, process innovation and business system innovation can be expected. The basic limitation of the research is the time period in which it was performed, which indicates a one-time recording of certain data without giving insight into long-term relationships and changes. The study uses data that comes from the manufacturing industry and IT industry in Croatia and it would be useful to conduct further empirical research that would confirm and supplement these results in other industries and other countries. The discussion of research findings encourages understanding managers of the relationship between market orientation and innovativeness in companies. This can contribute to creating additional value for consumers, but also increase the competitiveness of companies in the international market.

This study was conducted with the aim of developing the theory of market orientation and operationalization of the concept with emphasis on the future implications of market orientation. Companies are advised to develop innovative products, processes, and systems to increase their competitive advantage on the market. To improve business, companies should focus on consumer and competition needs as well as inter-company co-ordination, which is becoming increasingly important in business operations striving to maximize business growth on the market. Therefore, it is necessary to identify the needs of consumers or 
customers in order to come up with an innovative product - and the one that will be produced using new technologies. The first implication stems from the need to develop the market orientation of the company with the aim of creating superior value for the customer. Second, companies should strengthen their market orientation and innovativeness. Third, a market-oriented company can develop by increasing innovativeness and thus create an advantage over the competition. Fourth, all of the data was collected at a specific time, so variables and results are limited to that point in time. At the moment, this is a retrospective research because it was conducted four years ago and based on the results presented in this paper, it is not possible to draw conclusions about the "current" implications of the research.

The contribution of this research was manifested in the development of scientific thinking about the existence of a positive relationship between market orientation and innovativeness. Empirical contribution was achieved by defining a positive relationship of market orientation to innovativeness in the company. The scientific contribution is reflected in the fact that the research was conducted in the Republic of Croatia where such research is lacking. This research is important as a guide for companies on whether they should invest more in marketing and analytical skills to achieve success. It is suggested that future studies explore other business sectors to evaluate the results of this research, as well as to compare differences between individual business segments.

\section{REFERENCES}

[1] Kohli, A. K., Jaworski, B. J. (1990). Market orientation: the construct, research propositions, and managerial implications, The Journal of Marketing, Vol. 54, No. 4, pp. 1-18.

[2] Kohli, A. K. Jaworski, B. J. (1990). Market orientation: the construct, research propositions, and managerial implications, The Journal of Marketing, Vol. 54, No. 4, pp. 1-18.

[3] Narver, J. C. Slater, S. F. (1990). The effect of a market orientation on business profitability, Journal of Marketing, Vol. 4, pp. 20-35.

[4] Hurley, R. F. Hult, G. T. M. (1998). Innovation, market orientation, and organizational learning: an integration and empirical examination, The Journal of Marketing, Vol. 62, No. 8, pp. 42-54.

[5] Gunday, G. N. (2002). Market orientation and globalization among the Turkish clothing exporters, in Kaynak, E. and Sarvan, F. D. (Eds), The Impact of Globalization on World Business, Competition, Cooperation, Environment, and Development, Turkey: Proceedings of the IMDA 11th World Business Congress.

[6] Hult, G. T. M., R. F., Hurley R. F., Knight, G. A. (2004). Innovativeness: Its antecedents and impact on business performance. Industrial Marketing Management, Vol. 33, No. 5, pp. 429-438.

[7] Narver, J. C., Slater, S. F. MacLachlan D. L. (2004). Responsive and proactive market orientation and new-product success, The Journal of Product Innovation Management, Vol. 21, No. 5, pp. 334-347.

[8] Grinstein, A. (2008). The relationships between market orientation and alternative strategic orientations: A meta-analysis, European Journal of Marketing, Vol. 42, No. 1/2, pp. 115-134.

[9] Caruana, A., Pitt, L. Ewing, M. (2003). The Market Orientation-Performance Link: The Role of Service Reliability, The Service Industries Journal, Vol. 23, No. 4, pp. 25-41.

[10] Hult, G. T. M., Ketchen, D. J.,Slater, S. F. (2005). Market orientation and performance: an integration of disparate approaches. Strategic Management Journal, Vol. 26, No. 12, pp. 1173-1181.

[11] Narver, J. C.,Slater, S. F. (1990). The effect of a market orientation on business profitability, Journal of Marketing, Vol. 4, pp. 20-35.

[12] Narver, J. C. and Slater, S. F. (1990). The effect of a market orientation on business profitability, Journal of Marketing, Vol. 4, pp. 20-35.

[13] Shapiro Benson P. (1988). What the Hell Is Market Oriented, Harvard Business Review, Watertown: Harvard Business School Publication, Vol. 66, pp. 119-125.

[14] Jaworski, B. J. and Kohli, A. K. (1993). Market Orientation: Antecedents and Consequences, Journal of Marketing, Vol. 57, No. 8, pp. 53-70.

[15] Siguaw, Judy A., Simpson, Penny M. and Baker, T. L. (1998). Effects of Supplier Market Orientation on Distributor Market Orientation and the Channel Relationship: the Distributor Perspective. Journal of Marketing, Vol. 62, No. 3, pp. 99-112.

[16] Deshpandé R. , Farley, J. U. and Webster, F. E. (1993). Corporate Culture, Customer Orientation, and Innovativeness in Japanese Firms: A Quadrat Analysis, Journal of Marketing, Vol. 57, No. 1, pp. 23-38. 
[17] Gauzente, C. (2000). The dynamics of market-oriented change: An empirical exploration, Journal of Change Management, Vol. 1, No. 3, pp. 215-228.

[18] Homburg, C. and Pflesser, C. (2000). A multiple-layer model of market-oriented organizational culture: Measurement issues and performance outcomes, Journal of Marketing Research, Vol. 37, No. 11, pp. 449-462.

[19] Narver, J. C. and Slater, S. F. (1990). The effect of a market orientation on business profitability, Journal of Marketing, Vol. 4, pp. 20-35.

[20] Hult, G. T. M., R. F., Hurley R. F. and Knight, G. A. (2004). Innovativeness: Its antecedents and impact on business performance. Industrial Marketing Management, Vol. 33, No. 5, pp. 429-438.

[21] Rhee, J., Park, T. and Lee, D. H. (2010). Drivers of innovativeness and performance for innovative SMEs in South Korea: Mediation of learning orientation, Technovation, Vol. 30, No. 1, pp. 65-75.

[22] Hult, G. T. M., Ketchen, D. J. and Slater, S. F. (2005). Market orientation and performance: an integration of disparate approaches. Strategic Management Journal, Vol. 26, No. 12, pp. 1173-1181.

[23] Kirca, A. H., Jayachandran, S. and Bearden, W. O. (2005). Market orientation: A meta-analytic review and assessment of its antecedents and impact on performance. Journal of Marketing, No. 69, Vo. 2, pp. 24-41.

[24] Baker, W. E. and Sinkula, J. M. (2009). The complementary effects of market orientation and entrepreneurial orientation on profitability in small businesses, Journal of Small Business Management, Vol. 47, No. 4, pp. 443-464.

[25] Laforet, S. (2008). Size, strategic, and market orientation affects on innovation, Journal of Business Research, Vol. 61, No. 7, pp. 753-764.

[26] Dibrell, C., Craig, J. and Hansen, E. (2011). How managerial attitudes toward the natural environment aff ect market orientation and innovation, Journal of Business Research, Vol. 64, No. 4, pp. 401-407.

[27] Juhdi, H. N., Hong, T. S. and Juhdi, N. (2015). Market Orientation and Entrepreneurial Success: Mediating Role of Entrepreneurial Learning Intensity, Jurnal Pengurusan, Vol. 43, pp. 27-36.

[28] Boso N., Story V.M., Cadogan J. W. and Ashie E. (2015). Complementary Effects of Entrepreneurial Orientation, Market Orientation and Network Ties on Performance of Entrepreneurial Firms in a Developing Economy?, published 2015 in Ideas in Marketing: Finding the New and Polishing the Old, pp. 268-268.

[29] Cai, L., Liu, Q., Zhu, X. andDeng, S. (2015). Market orientation and technological innovation: the moderating role of entrepreneurial support policies, International Entrepreneurship and Management Journal, Vol. 11, No. 3, pp. 645-671.

[30] Shariff, M.N.M., Ahmad, N. R. and Hafeez, M. H. (2017). Moderating Role of Access to Finance on Entrepreneurial Orientation, Market Orientation, Learning Orientation and SMEs Performance of Gem and Jewelry Industry in Thailand. Journal of Business and Social Review in Emerging Economies, Vol. 3, No. 1, pp. 109-120.

[31] Šlogar, H. (2018). Procjena inovativnosti s aspekta poduzetničke orijentacije, tržišne orijentacije i orijentacije na učenje. Doctoral dissertation. Rijeka: University of Rijeka, Faculty of Economics.

[32] Hurley, R. F. and Hult, G. T. M. (1998). Innovation, market orientation, and organizational learning: an integration and empirical examination, The Journal of Marketing, Vol. 62, No. 8, pp. 42-54.

[33] Hult, G. T. M., R. F., Hurley R. F., and Knight, G. A. (2004). Innovativeness: Its antecedents and impact on business performance. Industrial Marketing Management, Vol. 33, No. 5, pp. 429-438.

[34] Jaworski, B. J. and Kohli, A. K. (1993). Market Orientation: Antecedents and Consequences, Journal of Marketing, Vol. 57, No. 8, pp. 53-70.

[35] Deshpandé R. , Farley, J. U. and Webster, F. E. (1993). Corporate Culture, Customer Orientation, and Innovativeness in Japanese Firms: A Quadrat Analysis, Journal of Marketing, Vol. 57, No. 1, pp. 23-38.

[36] Slater, S. and Narver, J. (1994). Does competitive environment moderate the market orientationperformance relationship? Journal of Marketing, Vol 58 , No. 1, pp. 46-55.

[37] Hult, G. T. M., R. F., Hurley R. F., and Knight, G. A. (2004). Innovativeness: Its antecedents and impact on business performance. Industrial Marketing Management, Vol. 33, No. 5, pp. 429-438.

[38] Nybakk, E. (2012). Learning orientation, innovativeness and financial performance in traditional manufacturing firms: a higher-order structural equation model, International Journal of Innovation Management, Vol.16, No. 5, pp. 28. 
[39] Hult, G. T. M., R. F., Hurley R. F., and Knight, G. A. (2004). Innovativeness: Its antecedents and impact on business performance. Industrial Marketing Management, Vol. 33, No. 5, pp. 429-438.

[40] Kirca, A. H., Jayachandran, S. and Bearden, W. O. (2005). Market orientation: A meta-analytic review and assessment of its antecedents and impact on performance. Journal of Marketing, No. 69, Vo. 2, pp. 24-41.

[41] Kaya, N. and Patton, J. (2011). The effects of knowledge-based resources, market orientation and learning orientation on innovation performance: An empirical study of Turkish firms, Journal of International Development, Vol. 23, No. 2, pp. 204-219.

[42] Ozkaya, H.E., Droge, C., Hult, G.T.M., Calantone, R. and Ozkaya, E. (2015). Market orientation, knowledge competence and innovation. International Journal of Research in Marketing, Vol. 32, No. 3, pp. 309-318.

[43] Didonet, S. R., Díaz, G. and Machado, A. M. (2016). Market Orientation and Sources of Knowledge to Innovate in SMEs: A Firm Level Study, Journal of technology management \& innovation, Vol. 11, No 3, pp. 1-20.

[44] Puspaningrum, A. (2017). The effect of market orientation and innovation on competitive advantages, Research Journal of Business and Management (RJBM), Vol. 4, No. 4, pp. 549-558.

[45] Thamrin. T. and Firma, M. (2018). The Influence of Market Orientation and Learning Orientation to Innovation of Kerupuk, Keripik, and Peyek in Padang City, Proceedings of the 2nd Padang International Conference on Education, Economics, Business and Accounting (PICEEBA-2 2018), Advances in Economics, Business and Management Research, Vol. 64., pp. 612-616.

[46] Sutarlan, S. (2018). Innovation and Market Orientation Model in Improving the Performance of BRI, Journal of Research in Marketing, Vol. 8, No. 3, pp. 698-706.

[47] Indriyani, R., Suprapto, W. and Calista, J. (2019), Market Orientation and Innovation: The Impact of Entrepreneurial Orientation among Traditional Snack Entrepreneurs in Sanan, Malang, Indonesia, In Proceedings of the 2nd International Conference on Inclusive Business in the Changing World, pp. 246-253.

[48] Šlogar, H. and Bezić, H. ( 2019b), The relationship between innovativeness and export in Croatian companies, Poslovna izvrsnost - Business excellence, Vol. 13, No. 2, pp.11-30.

[49] Narver, J. C., and Slater, S. F. (1990), The effect of a market orientation on business profitability, Journal of Marketing, Vol. 4, pp. 20-35.

[50] Nybakk, E. (2012), Learning orientation, innovativeness and financial performance in traditional manufacturing firms: a higher-order structural equation model, International Journal of Innovation Management, Vol.16, No. 5, pp. 28.

[51] Hult, G. T. M., R. F., Hurley R. F., and Knight, G. A. (2004). Innovativeness: Its antecedents and impact on business performance, Industrial Marketing Management, Vol. 33, No. 5, pp. 429-438.

\section{Article history:}

Received 7 November 2020

Accepted 15 December 2021 